This is a self-archived - parallel published version of this article in the publication archive of the University of Vaasa. It might differ from the original.

\title{
Interpersonal interaction in business triads: Case studies in corporate travel purchasing
}

\section{Author(s): Holma, Anne-Maria}

Title: Interpersonal interaction in business triads : Case studies in corporate travel purchasing

Year: $\quad 2012$

Version: Accepted version

Copyright (C)2012 Elsevier. This manuscript version is made available under the Creative Commons Attribution-NonCommercial-NoDerivatives 4.0 International (CC BY-NC-ND 4.o) license, https://creativecommons.org/licenses/by-nc-nd/4.o/

\section{Please cite the original version:}

Holma, A-M (2012). Interpersonal interaction in business triads : Case studies in corporate travel purchasing. Journal of Purchasing and Supply Management 18(2), 101-112. http://dx.doi.org/10.1016/j.pursup.2012.04.002 
ARTICLE IN PRESS May 2012

Journal of Purchasing and Supply Management

\title{
INTERPERSONAL INTERACTION IN BUSINESS TRIADS \\ - CASE STUDIES IN CORPORATE TRAVEL PURCHASING
}

\author{
Anne-Maria Holma \\ Chalmers University of Technology, Gothenburg, Sweden
}

\begin{abstract}
This study applies a triadic perspective to business triads of an industrial buyer, its service supplier and intermediary partners. The focus is on the structural, relational and cognitive features of interpersonal interaction. The study also takes into account strategic level interactions and interactions related to daily operations, thus providing insight into long and short-term interactive processes. Dedicated contacts and the social bonds between them provide important channels for both tacit and explicit information within and between the organisations, specifically at the operational level. The study contributes to service purchasing and supply literature by analysing complicated supply networks at the micro level, and by providing concepts and models for the study of interactions in triadic contexts. Managerial implications relate to the importance of creating trusting relationships within and between the organisations. The longitudinal approach adds to our understanding of ongoing service purchasing processes and the dynamism of business relationships.
\end{abstract}

Keywords: Interpersonal interaction, business triad, social capital, purchasing process. 


\section{Introduction}

Service purchasing is an ongoing process involving individuals at different organisational levels in buyer and supplier firms (Crosby et al., 1990; Feiser et al., 2011; Grönroos, 2007; Wang and Davis, 2008). Purchasing services is generally viewed as more challenging than purchasing goods. There is increasing interest among academic researchers in service purchasing (Baltacioglu et al., 2007; Tate et al., 2010), but comparatively little research has so far been conducted on inter-organisational socialization processes that create relational value in buyer-supplier relationships (Cousins et al., 2006).

Although three actors are often involved in service purchasing, since service provision is increasingly outsourced to professional service providers, business relationships are generally studied from a dyadic perspective. It was therefore decided to apply a triadic perspective in this study to business relationships between an industrial buyer, its service supplier and intermediary partners. The purpose of the study was to investigate interpersonal interaction in business triads in service purchasing processes. The focus is on the interactions between individuals at two levels: strategic and operational. The specific question addressed is: How does social capital develop in business triads in the service purchasing and supply context?

The empirical setting of the study is corporate travel purchasing. Corporate travel is a business consumption service focusing on individual employees (cf. Wynstra et al., 2006). The supply side consists of a large network of suppliers, and a business trip with multiple destinations usually involves several suppliers. Corporate travel buyers traditionally outsource service delivery to a business travel agency to simplify the network, and to guarantee suitable routes and rates for each trip. Corporate travel is generally the second or the third largest controllable cost for a company (Upton, 2005), which makes it worth monitoring. The amount of money spent on corporate travel-related services is increasing, while the resources 
allocated to managing the purchasing are not increasing proportionally (cf. Ellram et al., 2004; 2007). Corporations aim to decrease travel costs by reducing the cost per trip, not necessarily by diminishing the number of trips (Aquilera, 2008), thus putting pressure on efficient supply management. However, academic literature has paid little attention to effective management of corporate travel (Gustafson, 2011; Zhang et al., 2009).

In business research, there has been comparatively little application of social capital theory (Krause et al., 2006; Lawson et al., 2007). In this study, the structural, relational and cognitive dimension of social capital, as defined by Nahapiet and Ghospal (1998), are applied in order to understand interpersonal interactions in the core relationships. The study contributes to the service purchasing and supply literature by analysing complex supply networks at the microlevel, and by providing concepts and models for the study of interactions in triadic contexts. The longitudinal approach adds to our understanding of ongoing service purchasing processes. Managerial implications focus on the importance of interpersonal interaction and trust creation between the firms and between the levels.

The study is organised in the following way. Section two sets the theoretical framework by discussing interpersonal interaction and social capital in the organisational context, the specific features of interactions in triads and in corporate travel purchasing. The third section explains the research method and analysis procedures. Section four provides a description of the case firms and the informants, and the corporate travel purchasing function. Section five discusses the findings of the study. Finally, section six concludes the study, and discusses its contributions and avenues for further research.

\section{Literature review}

\subsection{Interpersonal interaction and social capital in business relationships}


Relationships can be seen as processes including product, service, information, social and financial exchanges develop over short-time episodes. These episodes lead, with time, to institutionalisation, adaptation, and long-term relationships (Håkansson, 1982). Business relationships are mainly established to manage financial transactions. However, organisations are also social entities, and business relationships develop in interactions among the individuals and groups of employees at different departments of the co-operating firms (Brennan and Turnbull, 1999; Cousins et al., 2006; Cunningham and Turnbull, 1982). Social exchange is important in building long-term relationships, and may exist between individuals even without service or product exchange (Brito and Nogueira, 2009; Ford et al., 2010; Håkansson, 1982; Price and Arnold, 1999). Networks of social relationships may also develop a life of their own, even when they were initially established for task-related activities (Marschan et al., 1996).

Social capital is a key term in the social network literature (Coleman, 1988), and it develops in network relationships. Social capital is the "sum of the actual and potential resources embedded within, available through and derived from the network of relationships" (Nahapiet and Ghoshal, 1998: 243). Nahapiet and Ghoshal (1998) divide social capital into three dimensions: structural, relational and cognitive.

The structural dimension refers to the pattern of connections between parties, meaning simply who you know and how you reach them to interact and communicate (Burt, 1992). Cousins et al. (2006: 854) discuss 'a formal socialization process', which implies that there are designated structures between buyers and sellers to communicate expectations and share useful information and knowledge. The employees create social bonds that may range from formal, organisational contacts to informal, personal ones (Perry et al., 2002; Sigala, 2007). Social bonds imply positive relationships and joint practices between the partners, providing 
access to resources and valuable information. Partners who develop the frequency and interaction of multiple contacts at different levels and various functions allow the creation of a social structure that benefits the involved parties in terms of the volume and diversity of information (Villena et al., 2011). Early access to information may increase its value (Burt, 1992).

The relational dimension is the result of socialisation processes, i.e. the nature of personal relationships that have been created through a history of interactions (Granovetter, 1992). While the structural dimension impacts primarily on accessibility, the relational dimension addresses the motivation to interact and exchange information (Nahapiet and Ghoshal, 1998). Trust is a key aspect of social capital, and an important motivating factor for interaction. Services are generally customised and people-intensive, and some level of trust is necessary for an exchange to occur (Halinen, 1996; Knoppen and Christiansee, 2007; Liljander and Strandvik, 1995). Personal relationships have the potential to apply powerful influences on organisational buying behaviour and relationship management. Strong, trusting personal relationships are used to solve problems and difficulties that arise during the service process (Bennett and Gabriel, 2001; Blois, 1997).

Nahapiet and Ghoshal (1998) recognized that separating relational and structural dimensions is challenging. Granovetter's (1992) concepts of relational and structural embeddedness explain the difference. The structural dimension implies social interaction within the actor's contacts in a specific social structure, which provides certain advantages. The relational dimension refers to the resources embedded in the established relationships, including trust (Tsai and Ghoshal, 1998).

The cognitive dimension of social capital describes "the resources providing shared representations, interpretations and systems of meaning among parties" (Nahapiet and 
Ghoshal, 1998: 244). In daily interactions, the cognitive dimension includes common codes and languages, and shared narratives to make sense of information and to categorize it (Coleman, 1988; Nahapiet and Goshal, 1998). The cognitive dimension facilitates a common understanding of collective goals, which help the people involved to see the potential value of information and resource exchange (Tsai and Ghoshal, 1998).

Social capital increases the efficiency of action and, in the form of high levels of trust, social capital, reduces opportunism and costly monitoring processes (Burt, 1992; Cousins et al., 2006; Putman, 1993). Social capital is owned mutually by the interacting parties. No one has exclusive ownership rights, and it cannot be traded easily (Burt, 1992; Nahapiet and Ghoshal, 1998). Villena et al. (2011) call for more reflections related to the risks and potential negative consequences associated with social capital. The creation and maintenance of specifically relational and cognitive dimensions of social capital are costly (Nahapiet and Ghoshal, 1998), and too little or too much social capital can hurt performance. For example, too much social capital can lead to loss of objectivity, ineffective decision-making (Bendoly et al., 2010; Granovetter, 1992; McFadyen and Cannella, 2004; Villena et al., 2011) and opportunism (Granovetter, 1985), and obstruct an employee's loyalty to his or her own company. Close relationships between a key contact person and a client may be harmful if the contact person leaves, and the client goes along to the new firm (Salmi, 2000).

\subsection{Interaction in triads}

Business relationships are generally studied from a dyadic perspective. Havila et al. (2004) propose that the perspective should be extended to triadic in situations where social interaction is one entity, i.e. when an increase in buyer-supplier interaction leads to decreasing buyer-intermediary interaction, and vice versa. 
Three actors are involved in many purchasing processes, for example in situations with a buyer and two competing suppliers (Choi and Wu, 2009; Dubois and Fredriksson, 2008; Peng et al., 2010; Wu and Choi, 2005; Wu et al., 2010), buyer, supplier and customer (Niranjan and Metri, 2008; Rossetti and Choi, 2008; van de Valk and van Iwardeen, 2011), and two buyers and a supplier (Choi and Kim, 2008). All outsourcing situations involve three actors. In the manufacturing industry, the buyer may create barriers between suppliers and end-customers, and continue to act as an intermediary. In a service context, in 'service triads' (van de Valk and van Weele, 2011; van de Valk and van Ivardeen, 2011), the buyer saves in administrative costs by not being involved in service delivery, but there is a risk of losing control over the purchasing. The buyer has to maintain close communication with the end customers and obtain feedback concerning supplier performance (Li and Choi, 2009; van der Valk and van Weele, 2011). Gadde and Hulthén (2009) noted that increasing interaction between the buyer and service provider is beneficial to the outcomes of outsourcing.

In addition to the concept of social capital presented in the previous section, the social network literature provides another frequently-used concept, the structural hole (Burt, 1992), which demonstrates the lack of connection between actors that are not directly linked. The concept is closely related to the concept of the bridge, which emphasises the advantages of bridging two disconnected networks. A firm, or an individual occupying the bridge position is likely to perform better because of superior access to information (Burt, 1992; Zaheer and Bell, 2005). Given greater homogeneity within than between groups, people bridging the structural holes between groups have earlier access to a wide diversity of information and have experience in translating information across groups (Burt, 2004). Social network theory also discusses the strength of the ties between the actors. Strong ties have higher levels of closeness and mutuality than weak ties. Strong ties increase the likelihood of sharing sensitive 
information, whereas weak ties provide access to a greater quantity and variety of information (Granovetter, 1973).

The supply chain literature applies the concept of 'a bride triad' (e.g. Stern and El-Ansary, 1992) to relationships where buyer and supplier have indirect contact via the intermediary. Havila (1996) classifies business triads into 'serial triads', and 'unitary triads' (see Fig. 1). In these kinds of triads, all three actors interact directly on successive occasions. The difference is in the nature of the relationship between the supplier and the customer, and the role of the intermediary. In a serial triad, interactions occur mainly between customer and supplier, while in a unitary triad, the division of work and the intermediary's role are adapted to each current situation (Havila, 1996). In different situations, a triad can act as a unitary triad, a serial triad or a bridge triad, depending on the context (Holma, 2009).

\section{PLEASE INSERT FIGURE 1 HERE}

\subsection{Corporate travel purchasing}

Douglas and Lubbe (2006:1131) define corporate travel as "travel undertaken by the employees of a particular organization that has a substantial travel volume and where travel arrangements are generally managed and consolidated into a centralized function". Corporate travel can be classified as a business consumption service, where the service is directed to individual employees (Wynstra et al., 2006), business travellers. Wynstra et al. (2006) consider business consumption services a secondary support for the buyer's business, and Fizsimmons and Noh (1998) position business travel in the category of 'low importance service'. However, corporate travel is a significant support function in most international corporations, which grows in importance when a firm internationalizes its operations. Social 
capital is created in face-to-face interactions, specifically important in cross cultural communication that requires travel (Aquilera, 2008; Faulconbridge et al., 2009).

Corporate travel purchasing is complex, with a large number of distribution channels selling a perishable service whose pricing is constantly changing (Cohen, 2001). Complexity is added by the number of suppliers involved in one single business trip with multiple destinations. In companies with large travel budgets, service delivery is generally outsourced to an intermediary, a business travel agency, which simplifies the supply network. However, both buyers and suppliers agree that there should be a person in the buyer organisation with the right to make decisions, and to take the responsibility of the travel management function (Mayer, 2007; Rose, 2008). The function evolved in the 1990s as a combination of technology and the willingness of airlines to negotiate corporate discounts (Rose, 2008). Industry reports emphasise effective travel management programmes that help save travel costs, arguing, for example, that travel budgets might be $25 \%$ higher without the efforts of a travel management department (Runzheimer International, 2000). Senior management has realised that considerable benefits can be achieved by applying greater management discipline. The majority of companies worldwide now have corporate travel policies, or at least unofficial policies of which employees are made aware (Douglas, 2008; Douglas and Lubbe, 2010; Mason, 2002). Douglas and Lubbe (2009) propose two main sources of motivation for the implementation of travel policies: first, to prevent travellers from over-spending and second, to demonstrate that the company has a supplier management mechanism. The trend in the majority of the companies is towards tighter policies, according to which business travellers are not allowed make independent decisions regarding their business trips (Hall, 2000; McCartney, 2008). 


\section{Research method and analysis procedures}

The current study is a case study of interpersonal interaction in the context of service purchasing and supply. The exploratory nature of the research speaks for the case study method. The study is based on abductive research, and characterized by systematic combining, where the theoretical and empirical fieldwork and case analysis advance simultaneously (Dubois and Gadde, 2002). In systematic combining, the context and boundaries of the phenomenon are constructed progressively, as theory interacts with method and empirical observations. Thus, the research object and its boundaries and context are emergent and unfolding outcomes of the research process (Dubois and Araujo, 2007). The study is longitudinal, and applies a retrospective processual approach (cf. Easton, 2010; Halinen and Törnroos, 2005).

Gummesson (2000) argues that academic researchers give inadequate thought to the importance of pre-understanding, in spite of the facts that it helps to understand the research setting and all its nuances, and that the absence of it means that the researcher has to spend considerable time gathering basic information. The author of the current study has extensive professional experience from different positions in the business travel industry, and as an active member of a buyer association. The author was also involved in developing a degree programme in travel management at the Institute of Marketing in Finland, a nationwide institution specialized in business education and in training and tutoring business travel buyers and suppliers in the programme between 2003 and 2010. Employees from small, midsize and large companies took part in the education, and they were responsible for both strategic and operational corporate travel functions. Discussions during the classes provided an understanding of an individual's role in the purchasing and supply processes. In written 
assignments, the students also analysed their own organisations' corporate travel purchasing, or their involvement in their clients' purchasing processes.

This study applies an embedded single case design (cf. Grünbaum, 2007; Perry, 2001), with several units of analysis in each case. The cases were selected using purposive sampling, more specifically intensity sampling, which involves collecting information-rich cases that have many examples of the phenomenon of interest, but not unusual or extreme cases (Lincoln and Cuba, 1985; Patton, 1990). A travel manager of a large international industrial enterprise was the starting point of the study. Small companies with small travel budgets generally have no need to centralise and manage the travel function (cf. Douglas and Lubbe, 2006: 1131).

The travel manager provided access to the most important partners during the last six years: three business travel agencies, two airlines and a hotel chain. Airline tickets are the largest travel related costs, constituting more than $50 \%$ of the travel budget, followed by accommodation costs. It was possible to conduct a retrospective longitudinal study, because the same boundary spanning individuals had been co-operating for a long time (the individual informants are presented in section 4.1). Furthermore, all the informants, at the time of interviews, had more than 10 years' experience in the travel industry.

The main empirical data used in this study was gathered in connection with a comprehensive study of business triads in corporate travel purchase (Holma, 2009) with in-depth interviews. The focus was on adaptations between three firms. The semi-structured interviews, which lasted from 1 to 2.5 hours, were conducted in May-August 2005. Critical Interview Technique based on Flanagan's Critical Incident Technique (1954), and developed by Chell (2004) was used. The technique is focused on events, explained in relation to what happened, why it happened, how it was handled, and what the consequences were. The technique makes it 
possible to investigate major events and processes, and their outcomes in terms of perceived effects. The aim is to understand the individual's perceptions, and take into account cognitive, affective and behavioral elements in the relationships. This technique, unlike unstructured interviews, enables the researcher to probe deeply by asking, for example, what happened next, why it happened, how it happened, and what the consequences were (Chell, 2004). Interpersonal interactions led to a lot of discussion in the interviews, which was a motivation to complement the data, and to conduct the current study. The author had continuous access (Gummesson, 2000) to the case firms and informants, which made it possible to supplement the data with phone conversations and informal conversations during the above-mentioned educational programme.

Previous research on situations with three actors has studied separate dyads (e.g. Gutek et al., 2002; Phillips Carson et al., 1997) and applied mathematical models (e.g. Khurana, 2002; Madhavan et al., 2004), thus neglecting the complexity of service encounters. The current study was inspired by the micronet approach (Halinen and Törnroos, 1998), where each of the three dyads embedded in the triads is analysed in the context of the other two dyads to which it is connected, and from both ends. Figure 2 visualises this quite complex research setting, with the nine business triads, in which the 15 dyads (the bolded lines) are embedded.

\section{PLEASE INSERT FIGURE 2 HERE}

The analysis went on throughout the interview process (cf. Cepeda and Martin, 2005), and the theoretical framework was modified. The interviews were transcribed, and a chronological description of the cases was created. Within-case analysis provided a description of each side of the relationship (cf. Yin, 2003). Each case was analysed in a three-stage interactive 
process: data reduction, data display, and conclusion-drawing (Miles and Huberman, 1994). The data was triangulated by comparing the buyer, supplier and travel agency informants' viewpoints (cf. Möllering et al., 2009).

\section{Interpersonal interaction in corporate travel purchase - case study findings}

This section is divided into three parts. The first presents the case firms and the informants. Thereafter follows a brief description of the development of the industrial enterprise's corporate travel purchase, and the actual analysis of the dimensions in interpersonal interaction.

\subsection{The case firms and informants}

The industrial enterprise concentrates its corporate travel to one agency at a time. During the study period, the industrial enterprise first used a local travel agency, then changed to travel agency 1 , and later to travel agency 2 . The same suppliers, airline A, airline B, and the hotel chain, provided services to the industrial enterprise throughout the study period. Figure 3 illustrates the firms and the time line of the study.

\section{PLEASE INSERT FIGURE 3 HERE}

The travel manager of the industrial enterprise is responsible for travel purchasing. However, her position requires a lot of travel, thus the travel manager herself is also a 'heavy user' of corporate travel services, which provides her with the possibility of evaluating the services 
and the supplier performance 'on the spot'. Another regular business traveller represents the end customer.

The airline informants (the account manager and the sales director) and the hotel chain informant (the sales manager) are the travel manager's contacts, with whom the co-operation is arranged. The general manager and the district manager represent travel agency 1 , and the Nordic manager, and the operation manager represent travel agency 2. The sales clerk was employed by all the three agencies. She interacts with the corporate travellers regularly on a daily basis. The informants represent the strategic and operational levels of the process. An additional 'level' is that of the traveller (end customer). Some of the informants have multiple roles in the corporate travel purchasing process because of their prior positions. Table 1 summarises (1) the informants, (2) the companies they represented at the time of the interviews, (3) their former employers through which they were connected to the industrial enterprise's travel purchasing, and (4) the functional levels.

\section{PLEASE INSERT TABLE 1 HERE}

\subsection{The development of the corporate travel purchasing process}

The travel management process can be roughly divided into the sub-processes before, during, and after the business trip. Figure 4 visualises the process and the involvement of the two levels in focus in the analyses. At the strategic level, interpersonal interaction implies contract negotiations and follow-up meetings, based on management reporting, analysis and reviews. Purchasing strategy is defined in the travel policy, which also directs travel bookings to the preferred suppliers. The operational level involves supply management and the daily interactions when arranging business trips, payment and travel settlement procedures. The 
interaction between these two levels is essential to implementation of purchasing strategies in practise.

\section{PLEASE INSERT FIGURE 4 HERE}

At the beginning of the study period, the industrial enterprise relied on the local travel agency for travel bookings. Travellers and secretaries made practical travel arrangements with a local travel agency that forwarded the bookings to the suppliers. Sometimes travel was arranged directly with the suppliers. No one at the industrial enterprise was primarily responsible for travel purchase. There were unofficial agreements between the directors of the firms, based on personal relationships. Business travel was small scale, and as the travel manager puts it “...it was very much about personal relationships with the partners".

Owing to internationalisation and thereby increased corporate travel, the industrial enterprise embarked on an extensive cost-cutting campaign, and appointed a travel manager to organise travel purchasing. She chose travel agency 1 as a new partner, because the local agency was did not offer global coverage. The new travel agency partner hired the local travel agency's clerks and, at the travel manager's request, established an in-house travel office on the premises of the industrial enterprise. All travel bookings were directed to this office, and travellers were not allowed to book directly with the suppliers. At the strategic level, the travel agency's personnel were left out of the communication loop between the industrial enterprise and the suppliers.

Development of the new technology changed the interaction patterns radically, and travel agency 1 was not able to keep pace with these developments. The industrial enterprise was pleased with their operational functions, but not with their strategic decisions, or to their 
ability to act for the industrial enterprise's best interests in the long-term. The travel manager negotiated a contract with travel agency 2 , and ended the relationship with travel agency 1 . Once more, the clerks followed the industrial enterprise. The development of the internet meant direct access for suppliers. The airlines saw opportunities to save on distribution costs by bypassing travel agencies. At the same time, rate structures changed, and travel purchasing became extremely complicated. The travel manager decided to continue cooperation with the travel agency, instead of starting to 'surf the internet' independently, as the travel manager puts it. The industrial enterprise relied on the travel agency's professionalism to find the most suitable alternatives for each business trip.

At the operational level, technology practically replaced interpersonal interactions with the suppliers. The travel agency developed self-booking tools in co-operation with the suppliers and the buyers. These tools provide the buyers, not only with a booking tool, but also with support for cost control and supplier management. The end customers have two options for booking their travel for simple trips, to book return tickets using the self-booking tool, and for complicated travel to use the travel agency clerks. There is no need for interpersonal interaction in simple bookings. However, complex travel with multiple destinations may include several conversations, either on the phone, or face-to-face.

\subsection{Dimensions of interpersonal interaction}

This section discusses interpersonal interaction in the core business triads by applying the structural, relational and cognitive dimensions of social capital introduced by Nahapiet and Ghoshal (1998). The study period is divided into three phases: triads with the local travel agency, triads with travel agency 1, and triads with travel agency 2. Each dimension includes analysis of both strategic and operational level interaction. There was no remarkable 
difference in interactions with the three suppliers. Consequently, to simplify the analyses, the suppliers are not addressed individually.

\subsubsection{Structural dimensions}

The structural dimension refers to the connections between parties, i.e. they interact and communicate (Burt, 1992). Interactions between the boundary spanning individuals of the firms are further divided into four dimensions (1) interaction patterns, (2) dyadic and triadic interactions, (3) direct and indirect interactions, and (4) interactions between the strategic and operations levels. These dimensions are discussed below, and summarised in Figures 5, 6, 7 and 8 .

\subsubsection{Interaction patterns}

Interaction patterns refer to the development of the social structures between the case firms. At the strategic level, interactions developed from non-existent to interactions in industrial enterprise - supplier dyads, and finally also interactions with the travel agency (see Fig. 5). At the operational level, the development was quite the opposite: beginning with interactions among all the three firms, to industrial enterprise - travel agency, and travel agency - supplier interactions. Finally, operational level interactions only occurred between the industrial enterprise and the travel agency.

\section{PLEASE INSERT FIGURE 5 HERE}


At the strategic level, and with travel agency 1, interactions occurred in one of the dyads (see Fig. 5). With travel agency 2, there were situations where three actors negotiated around the same table, as the following quote indicates:

...we quite often gather together, the travel agency's manager, the travel manager, and me. We do not directly negotiate fares, but we discuss how the co-operation could be realised regarding some specific issues. (Airline A, account manager)

At the operational level, the interactions advanced from three dyads to two dyads, and finally to one dyad. Fewer interpersonal interactions were needed because of self-booking.

\subsubsection{Direct and indirect interactions}

All the case firms and the individuals are connected to the industrial enterprise's travel purchasing process, either directly, or indirectly. Direct interaction among all the three actors occurred in two situations:

1. At the operational level in the triads with the local travel agency, and

2. At the strategic level in the triads with travel agency 2 .

However, there were differences in the timing of the interactions. At the operational level, the interactions were sequential. The general practise was that the local travel agency forwarded bookings to the suppliers. Confirmation of the travel arrangements proceeded in reverse. This situation can be compared to bridge triad interaction (Stern and El-Ansary, 1992). With travel agency 2 , at the strategic level the interactions were simultaneous, and the triad acted as a unitary triad (cf. Havila, 1996), because the travel agency's role changed from 'a ticket dealer' to 'a consultant and a technology provider', as the general manager of travel agency 1 put it. 
There were two situations with indirect interaction, such as interactions in serial triads (Havila, 1996).

1. At the strategic level, travel agency 1 interacted indirectly with the industrial enterprise and suppliers, as the following quote illustrates:

When service suppliers started to negotiate deals directly with the client [the industrial enterprise], we in the travel agency felt a little like outsiders. We did not communicate with the service suppliers any more. In some companies, the travel agency takes part in the negotiations, but in our case it was not so. We just found out later on what they had agreed, but we didn't take part in the meetings. (Travel agency, district manager)

2. At the operational level, travel agency 1 had direct interaction with the industrial enterprise, and with the suppliers. Because the travellers were not allowed to book directly with the suppliers, there were no interactions between the suppliers and the industrial enterprise.

\subsubsection{Interactions between strategic and operational levels}

At the beginning of the study period there was transactional purchasing, where practically all interpersonal interaction occurred at the operational level (see Figure 6). Occasionally, travellers or their secretaries booked travel directly with the suppliers. These interactions were less regular. Thus, there were two kinds of interactions: (1) regular bridge triad interactions: traveller - travel agency clerk - suppliers' sales clerk, and (2) dyadic, and less regular traveller - supplier interactions. 
Travel agency clerks mediated a great deal of information between the two levels (see Fig. 7). For example, the travel agency clerks were important in implementing the new travel policy during the transition period, and in communicating the cost-saving measures to the travellers. They were also an important feedback link:

They [travellers] know how things work, or don't work. We [travel agency clerks] get a lot of feedback, which is good, thanks to our long lasting relationships. It is easy for them to give us feedback, both positive and negative. (Clerk)

The dotted arrows visualise the less regular interactions across the levels.

\section{PLEASE INSERT FIGURE 7 HERE}

When the new booking technology was implemented, interpersonal interaction with the suppliers disappeared at the operational level, and the bridging role became even more central, as Figure 8 illustrates.

\section{PLEASE INSERT FIGURE 8 HERE}

\subsubsection{Relational dimension}

The relational dimension refers to the motivation to interact and exchange information (Nahapiet and Ghoshal, 1998). At the operational level, trust developed naturally between the 
travel agency clerks and the travellers, without formal contracts. The clerks were particularly important specifically during the transition period, as this supplier informant emphasises:

The contacts I have with the people who sit there [business travel agency clerks in the industrial enterprise's premises] are extremely important. It is very good that they stayed when the new travel agency took over. (Airline A, manager)

The trusting relationships between the clerks and the travellers were also important for strategic level decisions. However, the travel manager emphasises the importance of the buyer's professionalism, and the understanding of the specific conditions of the travel industry:

we [at the industrial enterprise] have to understand what they [at the business travel agency] are talking about so that we can commit ourselves...it is good to have good co-operation, but it can't be based on their understanding only. (Travel manager)

\subsubsection{Cognitive dimension}

The cognitive dimension refers to the sharing of contexts among the actors to obtain common language, codes and shared narratives (Nahapiet and Ghoshal, 1998). At the strategic level, the information exchanged at the first negotiations provided the foundation for understanding the common goals:

It was good when the client [the industrial enterprise] got a travel manager who said how they would like to have it, what was good and what was not good. She had suggestions of how to make it easier for them to work. (Airline B, director) 
All the parties not only got to know the partner company, but also the person they were cooperating with, as the following quote indicates.

When the situation is challenging, there is a lot of discussion... It is not only about signing your name on the paper, there are a lot of discussions, which strengthen the relationships, including personal relationships. (Hotel chain sales manager)

At the operational level, the in-house office provided a physical context for face-to-face interaction. Being located on the buyer's premises facilitates getting to know the customers. The district manager describes the clerk's relationships with the employees at the industrial enterprise in the following way:

My girls (the clerks) were treated as if they belonged to the industrial enterprise's personnel, because they were sitting there in the in-house office. Sometimes it felt as if they were on the staff of the client, and sometimes they were not know sure they belonged. (Travel agency 1, district manager)

Understanding the customer's needs is crucial in daily operations. According to the travel manager, knowledge of the buyer's travel patterns and of the individual travellers travel habits is essential. This kind of information is not always documented:

They [travel agency clerks] understand our travel needs, which are very demanding... We don't want to be served by a call center with 2000 clerks who serve all the clients. They do not understand the difference between our board members' and the mechanics' travel needs...we need to have a certain number of clerks who know our company extremely well, they have to know the places we are travelling to, the factories, and so on. (Travel manager)

Technology provided new opportunities to develop services and service processes, and to exchange information. However, all the parties agree that technology cannot replace human 
interaction. For example, the suppliers emphasised the importance of information meetings, where their representatives were able to meet the travellers.

\section{Discussion}

In the service purchasing context, studies including three actors became increasingly important, for reasons having to do with outsourcing. Outsourcing service purchasing involves always three actors. The roles of the actors, and the relationships between them change during the outsourcing process (see e.g. Lee and Choi, 2009; van der Valk and Van Ivardeen, 2011). Most business consumption services are contracted by the buying organisation, and used by many individual employees. Thus, purchasing business consumption services requires internal interaction and communication in addition to interaction with the external cooperating partners.

Villena et al. (2011: 563) emphasise the importance of multiple connections at different levels and various functions in order to create a social structure with different contact points for exchange of diverse information. The current triads include multiple connections with both dyadic and triadic interactions. Triadic interactions include sequential and simultaneous interactions. At the strategic level, the travel agency's increasingly important role encouraged simultaneous triadic interactions and open information exchange among the three partners. Furthermore, social interaction was noted as one entity (cf. Havila et al., 2004) between the two levels. The more operational level interactions, the fewer interactions were noticed at the strategic level, and vice versa. For example, when the suppliers' operational level disappeared, there was more strategic level interaction.

The current case study confirms the prior findings of trust being an important promoter of continuous interaction (see e.g. Inkpen and Tsang, 2005; Nahapiet and Ghoshal, 1998; Villena 
et al., 2011). The most enduring relationships were developed with the travel agency clerks, who were trusted throughout the study period, both by the travellers and by the strategic decision-makers.

Physical access is a prerequisite to the creation of cognitive social capital to contribute to a profound understanding of the goals of cooperation, despite the possibilities the technology provides, as the general manager of the travel agency puts it:

...it is still a human being doing this work. The internet has not reduced the need for personal relationships or the interactions between human beings. Quite on the contrary, it has even increased this need. (Travel agency 1, manager)

The in-house travel office on the client's premises enhanced close relationships and open information exchange.

A negative consequence of social capital creation from the travel agencies' point of view was the travel agency clerks' loyalty to the industrial enterprise, which exceeded their loyalty to their employer (cf. Salmi, 2000). From the industrial enterprise, and suppliers' perspective, this loyalty was, of course, helpful in the transition processes.

Previous research maintains that social interactions and overly close relationships between decision-makers at partner firms may have a negative influence on the businesses (Bendoly, et al., 2010; Granovetter, 1992; Villena et al., 2011). The travel manager agrees, and argues against overly close partner relationships:

You are not asked to come along on a skiing trip because you a nice guy, but because they [suppliers] want you to sign the contract. If you sign the contract because of the trip, you are totally useless to your employer. (Travel manager) 
Because of the long relationship and multiple level interactions, the travel agency clerks served as the bridge between the strategic and operational levels. The travellers had regular interactions with the clerks were regular, and strong ties with them developed, which enhanced information exchange regarding supplier performance. These interactions helped in implementing the travel policy and provided feedback on its applicability. Furthermore, the clerks had not only had contacts with the preferred suppliers, but also with a number of other suppliers, thus having a number of weak ties that provided access to a greater quantity and variety of information (cf. Granovetter, 1973). For the travel manager, it was important also to exchange information with other actors outside the triads. She emphasised training and benchmarking in order to understand the industry. She did not rely solely on the preferred partners, and was prepared to change partners if the relationship stagnated.

The current study provides an example of how the boundaries of the firms may fade in close cooperation. The triads do not exist solely between the firms, or between the employees of the cooperating firms. The triads can form ‘quasi-organizations' (cf. Håkansson and Ford, 2002) between, for example the travel agency - clerk - travel manager, clerk - traveller - travel manager, and supplier - clerk - traveller.

\section{Summary, conclusions and implications}

Based on the purchasing and supply literature, and the industrial network approach, this case study investigates interpersonal interactions between an industrial enterprise, its travel agency and service supplier partners. Cooperation involves two main levels: the operational level with travel arrangements and supplier management, and the strategic level where the purchasing strategy and process development are defined. The longitudinal case study covers the industrial enterprise's relationships with three different travel agency partners, and three 
preferred suppliers. The longitudinal case study reveals that interpersonal interaction takes on different features each time the industrial enterprise changes the travel agency partner, which occurs due to changes in the business environment. Interpersonal interaction is analysed with the help of the three social capital dimensions (Nahapiet and Ghoshal, 1998): structural, relational and cognitive. These dimensions are interrelated; social structures are necessary for relational communication and information exchange. The relational dimension enhances longterm cooperation, and the cognitive dimension is a prerequisite for commitment to common goals.

\subsection{Theoretical contributions}

This study has several dimensions. First, it investigates cooperation in triadic constellations, which is still scarce, specifically in the service purchasing context. Second, the study addresses both the purchasing and supply sides, and thus provides multiple perspectives on the purchasing processes. Third, the importance of multiple connections is emphasised by including two interaction levels in the study, operational and strategic. The findings contribute to the service purchasing and supply chain literature by analysing complex supply networks at the micro-level, when it comes both to the triad as part of a larger network, and individuals in the triads. For relationship marketing and management, and for purchasing and supply researchers, the study provides concepts and models for the study of interaction in triads.

The longitudinal approach adds our understanding of ongoing service purchasing processes, thus contributing to relationships dynamism research (cf. Halinen et al., 1999). Li and Choi (2009) noticed that in service outsourcing, the relationship structures between three actors are more dynamic than those in the manufacturing industries. Thus, the longitudinal approach is important specifically in service purchasing and service outsourcing contexts. Furthermore, 
the study also takes into account, in addition to strategic level interactions, interactions related to daily operations, thus providing insights into short-time interactive processes (cf. Holmlund, 2004).

\subsection{Managerial implications}

The importance of interpersonal interaction between firms and between levels is highlighted. Dedicated contact representatives who have the knowledge of processes and services are valuable. The social bonds that develop between the individuals provide channels for information exchange. At the operational level, exchange of tacit information is essential. It is also important to create trust and commitment both with the counterparts and with employees of the corporation.

Technology provides new opportunities for purchasers and suppliers. However, technology cannot replace all personal contacts. Employees still need face-to-face communication. Corporate travellers travel to meet their counterparts, even though some of the communication occurs with the help of video and internet conferences. Also organising corporate travel requires interpersonal interaction, despite self-booking possibilities. Interpersonal interaction creates understanding of common goals. In situations where purchases are arranged via an intermediary, the power may shift from the buyer to the supplier ( $\mathrm{Li}$ and Choi, 2009). Close cooperation with the intermediary may eliminate this risk, but does not free the buyer from the obligation to communicate with the suppliers and the end-users to monitor the purchase.

\subsection{Limitations and further research}


This case study is limited to one specific service industry, and one specific business consumption service. Findings from other service industries with triadic relationships could bring out new aspects, and give additional value to the research. Furthermore, the core triads consist of an industrial enterprise, its service supplier and travel agency partners. These actors have their own roles, and beyond the common goal, they have their own goals, which may even be conflicting. Thus, in another context, with a different triadic setting, interpersonal interaction may have different features. Including different industries in one study would also be useful. However, investigating business triads may be complicated, specifically if several levels of interaction are included.

Trust is a widely researched concept in business research. However, trust is generally regarded as a dyadic concept, even though the assumptions of the counterpart's trustworthiness may be formulated by a third party's judgment (Svensson, 2004). The findings of this study might be deepened by studying trust in the triads at the interorganisational and at the interpersonal level, and between different hierarchical levels of the partner organisations.

Methodologically, when time allows, an ethnographic, or an action research approach could be conducted (cf. Brennan and Canning, 2003), or a longitudinal research project with analysis of data collected at different points of time. The qualitative case study approach applied in the current study does not allow for the measurement of the interactions, or evaluation of their quality and output. These topics also call for further research. 


\section{List of references}

Aquilera, A., 2008. Business travel and mobile workers. Transportation Research Part A 42, 1109-1116.

Baltacioglu, T., Ada, E., Kaplan, M.D., Yurt, O., Kaplan, Y.C., 2007. A New Framework for Service Supply Chains. The Service Industries Journal 27 (2), 105-124.

Bendoly, E., Croson, R., Goncalves, P., Schultz, K., 2010. Bodies of knowledge for research in behavioural operations. Production and Operations Management. Journal of Operations Management 19 (4), 434-452.

Bennett, R., Gabriel, H., 2001. Reputation, trust and supplier commitment: the case of shipping company/seaport relations. Journal of Business and Industrial Marketing 16 (6), 424-438.

Blois, K., 1997. Are Business-to-Business Relationship Inherently Unstable? Journal of Marketing Management 13 (5), 367-382.

Brennan, R., Canning, L., 2003. Adaptation Processes in Supplier-Customer Relationships. Journal of Customer Behavior 1 (2 June), 117-144.

Brennan, R., Turnbull, P.W., 1999. Adaptive Behaviour in Buyer-Supplier Relationships. Industrial Marketing Management 28 (5), 481-495.

Brito, C., Nogueira, M., 2009. Capabilities exchange through business interaction: An empirical investigation of a client - IT supplier relationship. Journal of Purchasing \& Supply Management 15 (4), 227-239.

Burt, R., 1992. Structural Holes. Cambridge. MA: Harvard University Press.

Burt, R., 2004. Structural Holes and Good Ideas. The American Journal of Sociology 110 (2), 349-99. 
Cepeda, G., Martin, D., 2005. A review of case studies publishing in Management Decision 2003-2004, Guides and criteria for achieving quality in qualitative research. Management Decision 43 (5/6), 851-876.

Chell, E., 2004. Critical incident technique. In: Cassell, C. and Symon, G. (Eds). Essential guide to qualitative methods in organizational research. London: Sage, 2004, pp. 45-60.

Choi, T., Kim, Y., 2008. Structural Embeddedness and Supplier Management: A Network Perspective. Journal of Supply Chain Management 44 (4), 5-13.

Choi, T.Y., Wu Z., 2009. Triads in supply networks: Theorizing buyer-supplier-supplier relationships. Journal of Supply Chain Management 45 (1), 8-25.

Cohen, A., 2001. How to buy business travel services. Supply Management July 2001.

Coleman, J.S., 1988. Social capital in the creation of human capital. American Journal of Sociology 94, 95-120.

Cousins, P.D., Handfield, R.B., Lawson, B., Petersen, K.J., 2006. Creating supply chain relational capital: The impact of formal and informal socialization processes. Journal of Operations Management 24 (6), 851-863.

Crosby, L.A., Evans, K.R., Cowles, D., 1990. Relationship quality in services selling: an interpersonal influence perspective 16 (2), 35-51.

Cunningham, M., Turnbull, P., 1982. Interorganizational personal contact patterns. In: Håkansson H. (Ed). International Marketing and Purchasing of Industrial Goods. An Interaction Approach, pp. 303-316. John Wiley and Sons: Chichester. Douglas, A., 2008. A survey of corporate travelers in South Africa: Towards a model for travel policy compliance. University of Pretoria. Doctoral Thesis. 
Douglas, A., Lubbe, B., 2010. An Empirical Investigation into the Role of Personal-Related Factors on Corporate Travel Policy Compliance. Journal of Business Ethics 92 (3), 451-461.

Douglas, A., Lubbe, B., 2006. Identifying value conflicts between stakeholders in corporate travel management by applying the soft value management model. Tourism Management 27 (6), 1130-1140.

Dubois, A., Araujo, L., 2007. Case research in purchasing and supply management: Opportunities and challenges. Journal of Purchasing and Supply Management $13(3), 170-181$.

Dubois, A., Fredriksson, P., 2008. Cooperating and competing in supply networks: Making sense of a triadic sourcing strategy, Journal of Purchasing \& Supply Management 14 (3), 170-179.

Dubois, A., Gadde, L-E., 2002. Systematic combining: an abductive approach to case research. Journal of Business Research 55 (7), 553-560.

Easton, G., 2010. Case study research: A critical realist approach. Industrial Marketing Management 39 (1), 118-128.

Ellram, L., Tate, W., Billington, C., 2007. Services Supply Management: The Next Frontier for Improved Organizational Performance. California Management Review 49 (4), 44-66.

Ellram, L., Tate, W., Billington, C., 2004. Understanding and Managing the Services Supply Chain. The Journal of Supply Chain Management 40 (4), 17-32.

Faulconbridge, J.R., Beaverstock, J.V., Derudder, B., Witlox, F., 2009. Corporate ecologies of business travel in professional service firms, working towards a research agenda. European Urban and Regional Studies 16 (3), 295-308. 
Feisel, E., Hartmann, E., Guinipero, L., 2011. The importance of the human aspect in the supply function: Strategies for developing PSM proficiency. Journal of Purchasing \& Supply Management 17 (1), 54-67.

Fitzsimmons, J., Noh, J., 1998. Purchasing business services. Journal of Business and Industrial Marketing 13 (4/5), 370-380.

Ford, D., Gadde, L-E., Håkansson, H., Snehota, I., Waluszewski, A., 2010. Analysing Business Interaction. IMP Journal 4, (1), 82-103.

Flanagan, J.C., 1954. The critical incident technique. Psychological Bulleting 51(4) 327-359.

Gadde, L-E., Hulthén, K., 2009. Improving logistics outsourcing through increasing buyerprovider interaction. Industrial Marketing Management 38 (6), 633-640.

Granovetter, M., 1992. Problems of explanation in economic sociology, In: Networks and Organizations, Nohria, N., Eccles, R.G. (Eds.) Harvard Business School Press: Boston, MA, pp. 35-56.

Granovetter, M., 1985. Economic action and social structure: the problem of embeddedness. The American Journal of Sociology 91 (3), 481-510.

Granovetter, M., 1973. The Strength of Weak Tie. American Journal of Sociology 78 (6) May, 1360-1380.

Grünbaum, N., 2007. Identification of ambiguity in the case study research typology: what is a unit of analysis? Qualitative Market Research An International Journal 10 (1), 78-97.

Grönroos, C., 2007. Service Marketing and Management, Customer Management in Service Competition. Third Edition, John Wiley and Sons, Ltd.

Gummesson, E., 2000. Qualitative Methods in Management Research. Sage Publications, Incl. 
Gustafson, P., 2012. Managing business travel: Developments and dilemmas in corporate travel management. Tourism Management 33 (2), 276-284.

Gutek, B., Groth, M., Bennett, C., 2002. Achieving service success through relationships and enhanced encounters. Academy of Management Executive 16 (4), 132-144.

Halinen, A., 1996. Service Quality in Professional Business Services: A Relationship Approach. Advance in Services Marketing and Management 5, 315-341.

Halinen, A., Salmi, A., Havila, V., 1999. From dyadic change to changing business network: an analytical framework. Journal of Management Studies 36 (6), 779-794.

Halinen, A., Törnroos J- $\AA$., 2005. Using case methods in the study of contemporary business networks. Journal of Business Research 58 (9), 1285-1297.

Halinen, A., Törnroos J-Å., 1998. The role of embeddedness in the evolution of business networks. Scandinavian Journal of Management 14 (3), 187-205.

Hall, I., 2000. We want value for money - consistently. ITM Newsline 28, March 2000.

Havila, V., 1996. International Business-Relationship Triads, A study of the changing role of the intermediating actor. Doctoral Thesis, Department of Business Studies, Uppsala University 1996.

Havila, V., Johanson, J., Thilenius, P., 2004. International business-relationship triads. International Marketing Review 21 (2), 172-186.

Holma, A., 2009. Adaptation in triadic business relationship settings: A study in corporate travel management. Doctoral Thesis. Publications of Hanken School of Economics 207.

Holmlund, M., 2004. Analyzing business relationships and distinguishing different interaction levels. Industrial Marketing Management 33 (4), 279-287. 
Håkansson, H., 1982. An Interaction Approach, In: Håkan Håkansson (Ed). International Marketing and Purchasing of Industrial Goods. An Interaction Approach. John Wiley and Sons: Chichester, pp. 10-27.

Håkansson, H., Ford, D., 2002. How should companies interact in business networks? Journal of Business Research 55 (2), 133-139.

Inkpen, A.C., Tsang, E.W.K., 2005. Social capital, networks, and knowledge transfer. Academy of Management Review 30 (1), 146-165.

Khurana, R., 2002. Market triads: A Theoretical and Empirical Analysis of Market Intermediation. Journal for the Theory of Social Behavior 32 June 2002 (2), 239-262.

Knoppen, D., Christiaanse, E., 2007. Interorganizational adaptation in supply chains: a behavioral perspective. The International Journal of Logistics Management 18 (2), 217-237.

Krause, D.R., Handfield, R.B.,Tyler, B.B., 2007. The relationships between supplier development, commitment, social capital accumulation and performance improvement. Journal of Operations Management 25, 528-545.

Lawson, B., Tyler, B.B., Cousins, P.D. 2008. Antecedents and consequences of social capital on buyer performance improvement. Journal of Operations Management 26 (3), $446-460$.

Li, M., Choi, T., 2009. Triads in services outsourcing: bridge, bridge decay and bridge transfer. Journal of Supply Chain Management 45 (3), 27-39.

Lincoln, Y., Guba, E., 1985. Naturalistic Inquiry. Sage Publications, Inc.

Liljander, V., Strandvik, T., 1995. The nature of customer relationships in services. Advances in Services Marketing and Management (4), 1-34. 
Madhavan, R., Gnyawali, D.R, He J., 2004. Two’s company, three's crowd? Triads in cooperative - competitive networks. Academy of Management Journal 47 (6), 918-927.

Marschan, R., Welch, D., Welch, L., 1995. Control on Less-hierarchical Multinationals: the Role of Personal Networks and Informal Communication. International Business Review 5 (2), 137-150.

Mason, K., 2002. Future Trends in Business Travel Decision Making. Journal of Air Transport Management 7 (1), 47-69.

Mayer, D., 2007. Delving into the formulas of success. Business Travel News May 21, 4-30. McFadyen, M.A., Cannella Jr., A.A., 2004. Social capital and knowledge creation: diminishing returns of the number and strength of exchange relationships. Academy of Management Journal 47 (5), 735-746.

McCartney, S., 2008. Is Your Boss Spying On Your Upgrades? Wall Street Journal Travel, Tuesday, August 12.

Miles, M., Huberman, M., 1994. Qualitative Data Analysis (2nd edition). Thousand Oaks, CA: Sage Publications.

Möllering, G., Zerbini, F., Grosso M., 2009. Mediated category management: How third parties enable the implementation of buyer-seller collaboration. Finanza Marketing e Produzione 9 (2), 11-28.

Nahapiet, J., Ghoshal, S., 1998. Social capital, intellectual capital and the organizational advantage. Academy of Management Review 38 (2), 242-266.

Niranjan, T.T, Metri, B.A., 2008. Client-vendor-end user triad: A service quality model for is/ites outsourcing. Journal of Services Research 8 (1), 123-138.

Patton, M., 1990. Qualitative evaluation and research methods. Newbury Park California. Sage 1990. 
Peng, T-J.A., Lin, N-J., Martinez, V., Yu, C-M.J. 2010. Managing Triads in a Military Avionics Service Maintenance Network in Taiwan. International Journal of Operations \& Production Management 30 (4), 398-422.

Perry, C., 2001. Case Research in Marketing. The Marketing Review 1 (3), 303-323.

Perry, C., Cavaye, A., Coote, L., 2002. Technical and social bonds within business-tobusiness relationships. Journal of Business and Industrial Marketing 17 (1), 7588.

Phillips Carson, P., Carson, K.D., Knouse, S.B., Roe, W.C., 1997. Balance theory applied to service quality: a focus on the organization, provider and consumer triad. Journal of Business and Psychology 12 (2), 99-120.

Price, L.L., Arnould, E.J., 1999. Commercial friendship: Service provider-client relationships in context. Journal of Marketing 63 (4), 38-56.

Putman, R.D., 1993. The prosperous community: social capital and public life. The American Prospect 13, 35-42.

Rose, N., 2008. The Changing Role of Travel Management. PhoCusWright Inc.

Rossetti, C., Choi, T., 2008. Supply management under high goal incongruence: an empirical examination of disintermediation in the aerospace supply chain. Decision Sciences 39 (3), 507-540.

Runzheimer International, 2000. Runzheimer Reports on Travel Management I and II December 2000, 20 (7).

Salmi, A., 2000. Corruption - do we skip unpleasant issues of business interaction? Proceedings of the $16^{\text {th }}$ IMP conference, Bath, UK, 7-9.9.2000.

Sigala, M., 2007. Investigating the internet's impact on interfirm relations. Evidence from the business travel management distribution chain. Journal of Enterprise Information Management 20 (3), 335-355. 
Stern, L.W., El-Ansary, A.I., 1992. Marketing Channels. Prentice-Hall, Inc, Englewood Cliffs, NJ.

Svensson, G., 2004. Triadic trust in business networks: a conceptual model and empirical illustration. European Business Review 16 (2), 165-190.

Tate, W., Ellram, L., Bals,. L., Hartmann, E., vand der Valk, W., 2010. An Agency Theory perspective on the purchase of marketing services. Industrial Marketing Management 39 (5), 806-819.

Tsai, W., Ghoshal, S., 1998. Social capital and value creation: The role of intrafirm networks. Academy of Management Journal 41 (4), 464-476.

Upton, G., 2005. Keeping corporate travel costs under control. FinanceWeek 22 June 2005. van de Valk, W., van Iwaarden, J., 2011. Monitoring in service triads consisting of buyers, subcontractors and end customers. Journal of Purchasing \& Supply Management 17 (3), 198-206.

van de Valk, W., van Weele, A., 2011. Business service triads: A new area for service research, IPSERA 2011 Conference Proceedings 978-94-6178-001-0, 14081421.

Villena, V.H., Revilla, E., Choi, T.Y., 2011. The dark side of buyer-supplier relationships: A social capital perspective. Journal of Operations Management 29 (3), 561-576.

Wang, S., Davis, L., 2008. Stemming the tide: dealing with the imbalance of customer relationships quality with the key contact employee versus with the firm. Journal of Services Marketing 22 (7), 533-549.

Wu, Z., Choi, T.Y., 2005. Supplier-supplier relationships in the buyer-supplier triad: building theories from eight case studies. Journal of Operations Management 24(1), 2752. 
Wu, Z., Choi, T., Rungtusanatham, M., 2010. Supplier-supplier relationships in buyersupplier-supplier triads: implications for supplier performance. Journal of Operations Management 28 (2), 115-123.

Wynstra, F., Axelsson, B., van de Valk, W., 2006. An application-based classification to understand buyer-supplier interaction in business services. International Journal of Service Industry Management 17 (5), 474-496.

Yin, R., K., 2003. Case study research, Design and Methods. Third Edition. Sage Publications Thousand Oaks.

Zaheer, A., Bell, G.G., 2005. Benefiting from network position: firm capabilities, structural holes, and performance. Strategic Management Journal 26 (9), 809-825.

Zhang, X., Song, H., Huang, G.Q., 2009. Tourism supply chain management: A new research agenda. Tourism Management 30, 345-358. 


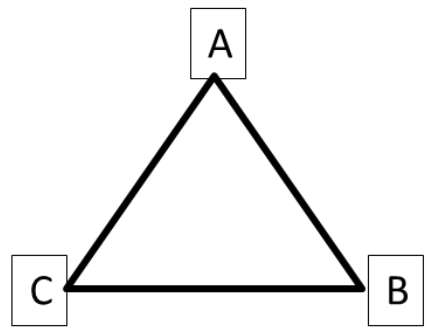

Unitary triad

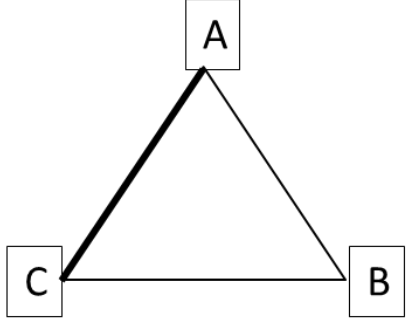

Serial triad

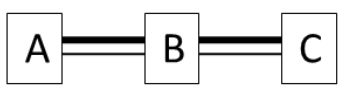

Bridge triad

= more intense interaction; $\quad-\quad=$ less intense interaction

$\mathrm{A}=$ customer $; \mathrm{B}=$ intermediary $; \mathrm{C}=$ supplier

Fig. 1: Different types of triad interactions. (Sources: Havila, 1996; Stern/El-Ansary, 1992) 

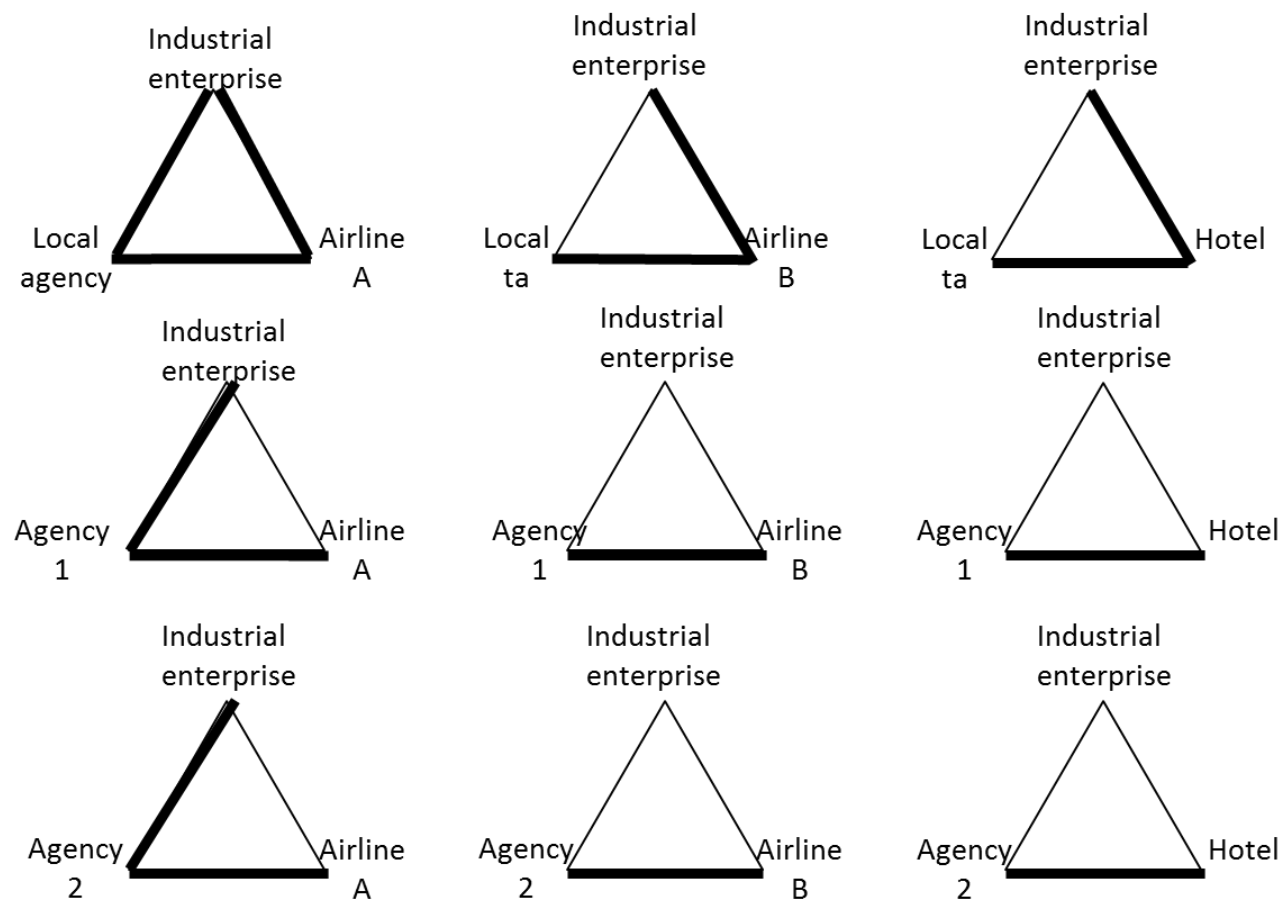

Fig. 2: The units of analysis. 


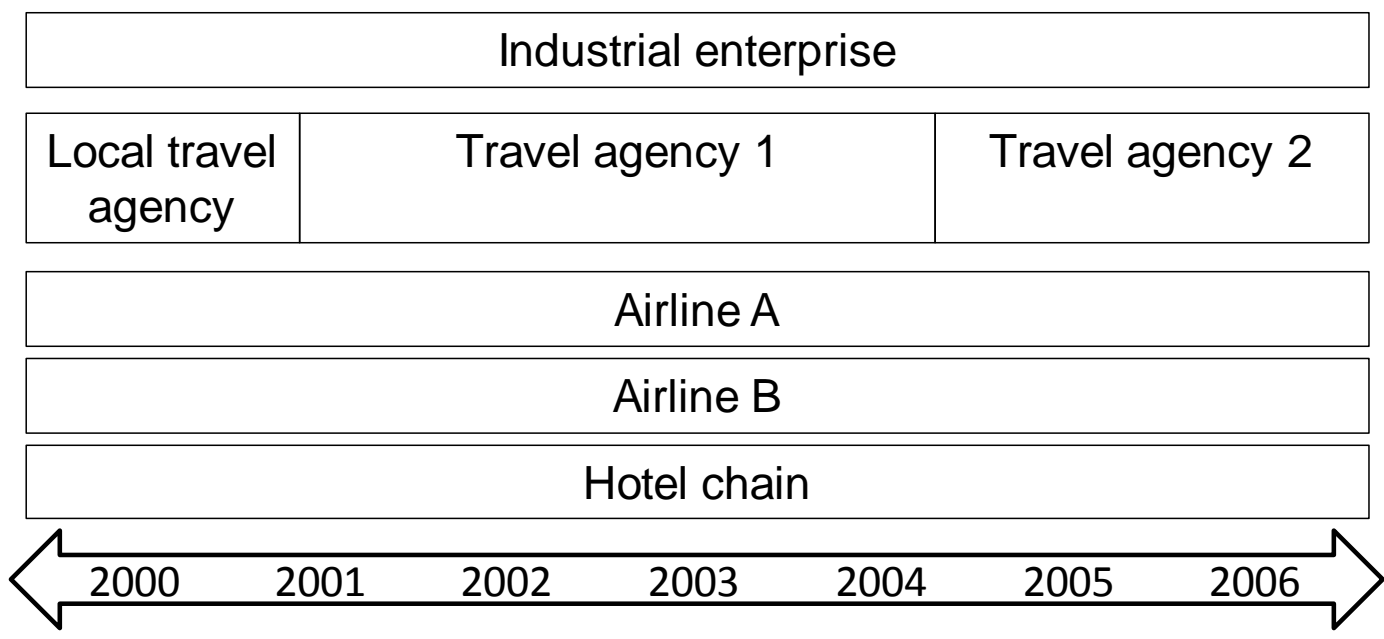

Fig. 3: The actors and the time line of the research. 


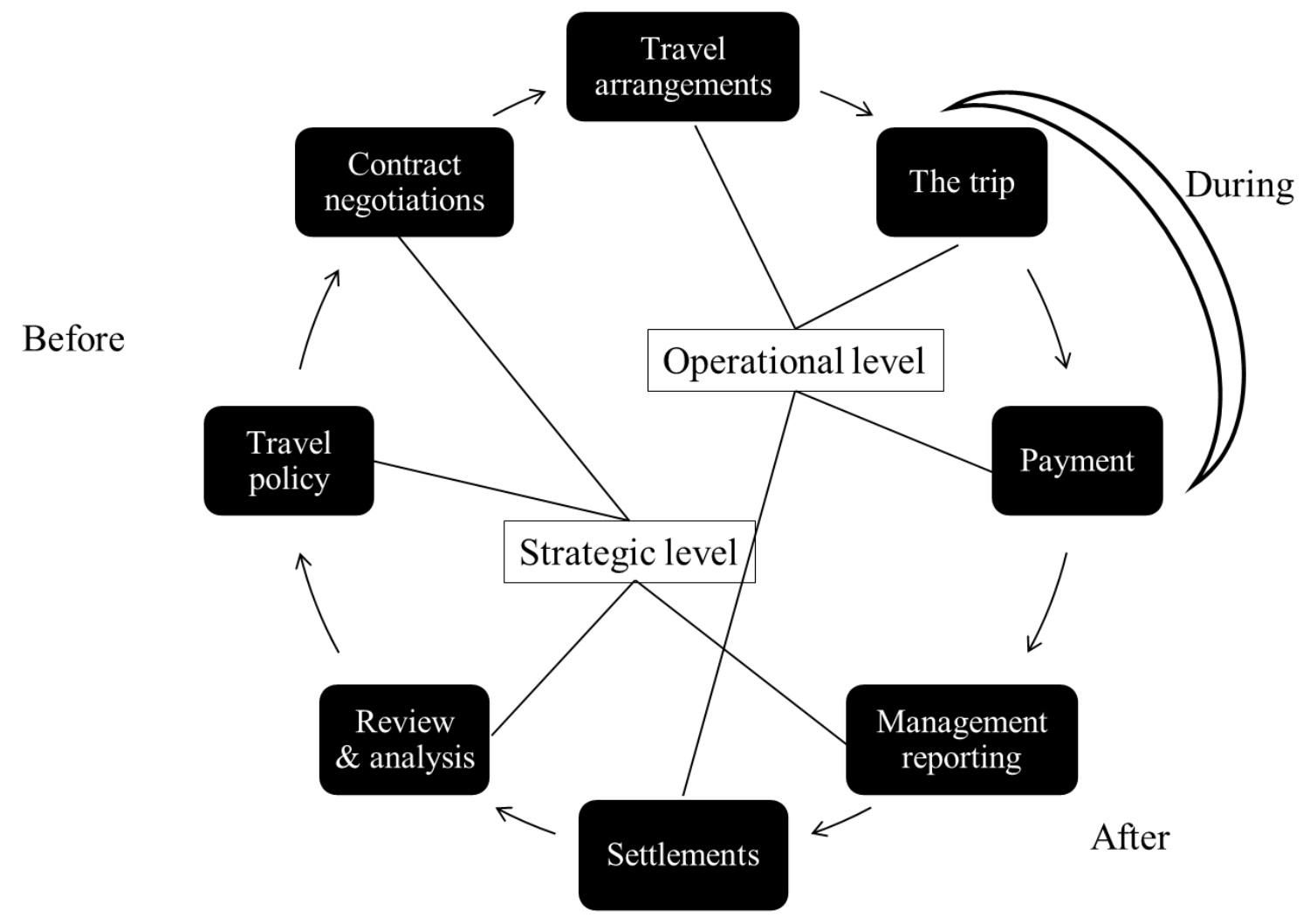

Fig. 4: Corporate travel purchasing process. 


\begin{tabular}{|c|c|c|c|}
\hline The triads & $\begin{array}{c}\text { Industrial enterprise - } \\
\text { local travel agency - } \\
\text { suppliers }\end{array}$ & $\begin{array}{c}\text { Industrial enterprise - } \\
\text { travel agency } 1 \text { - } \\
\text { suppliers }\end{array}$ & $\begin{array}{c}\text { Industrial enterprise - } \\
\text { travel agency } 2 \text { - } \\
\text { suppliers }\end{array}$ \\
\hline \multicolumn{4}{|c|}{ Strategic level } \\
\hline $\begin{array}{l}\text { Interaction } \\
\text { patterns }\end{array}$ & $\begin{array}{l}\text { No interpersonal } \\
\text { interaction }\end{array}$ & $\begin{array}{l}\text { (1) Industrial enterprise - } \\
\text { service suppliers }\end{array}$ & $\begin{array}{l}\text { (1) Industrial enterprise - } \\
\text { travel agency } 2 \\
\text { (2) Industrial enterprise - } \\
\text { service suppliers } \\
\text { (3) Travel agency 2 - } \\
\text { service suppliers }\end{array}$ \\
\hline $\begin{array}{l}\text { Dyadic and } \\
\text { triadic } \\
\text { interactions }\end{array}$ & $\begin{array}{l}\text { No interpersonal } \\
\text { interaction }\end{array}$ & Dyadic: One dyad & Triadic \\
\hline $\begin{array}{l}\text { Direct and } \\
\text { indirect } \\
\text { interactions }\end{array}$ & $\begin{array}{l}\text { No interpersonal } \\
\text { interaction }\end{array}$ & $\begin{array}{l}\text { Supplier } \\
=\text { direct interactions } \\
=\text { indirect interactions }\end{array}$ & $\begin{array}{l}\text { Travel agency } \\
\text { Supplier } \\
\text { Simultaneous triadic } \\
\text { interactions }\end{array}$ \\
\hline \multicolumn{4}{|c|}{ Operational level } \\
\hline $\begin{array}{l}\text { Interaction } \\
\text { patterns }\end{array}$ & $\begin{array}{l}\text { (1) Industrial enterprise - } \\
\text { local travel agency } \\
\text { (2) Industrial enterprise - } \\
\text { service suppliers } \\
\text { (3) Local travel agency - } \\
\text { service suppliers }\end{array}$ & $\begin{array}{l}\text { (1) Industrial enterprise - } \\
\text { travel agency } 1 \\
\text { (2) Travel agency } 1 \text { - } \\
\text { service suppliers }\end{array}$ & $\begin{array}{l}\text { (1) Industrial enterprise - } \\
\text { travel agency } 2\end{array}$ \\
\hline $\begin{array}{l}\text { Dyadic and } \\
\text { triadic } \\
\text { interactions }\end{array}$ & Dyadic: Three dyads & Dyadic: Two dyads & Dyadic: One dyad \\
\hline $\begin{array}{l}\text { Direct and } \\
\text { indirect } \\
\text { interactions }\end{array}$ & $\begin{array}{l}\text { Industrial enterprise } \\
\text { Supplier } \quad \text { Travel agency } \\
\text { Sequential dyadic } \\
\text { interactions }\end{array}$ & $\begin{array}{l}\text { Supplier } \begin{array}{c}\text { Travel agency } \\
=\text { direct interactions } \\
-=\text { indirect interactions }\end{array}\end{array}$ & $\begin{array}{l}\text { Industrial enterprise } \\
-=\text { dravel agency } \\
-=\text { indirect interactions } \\
-=\text { interactions }\end{array}$ \\
\hline
\end{tabular}

Fig. 5: Structural dimension of interpersonal interactions. 


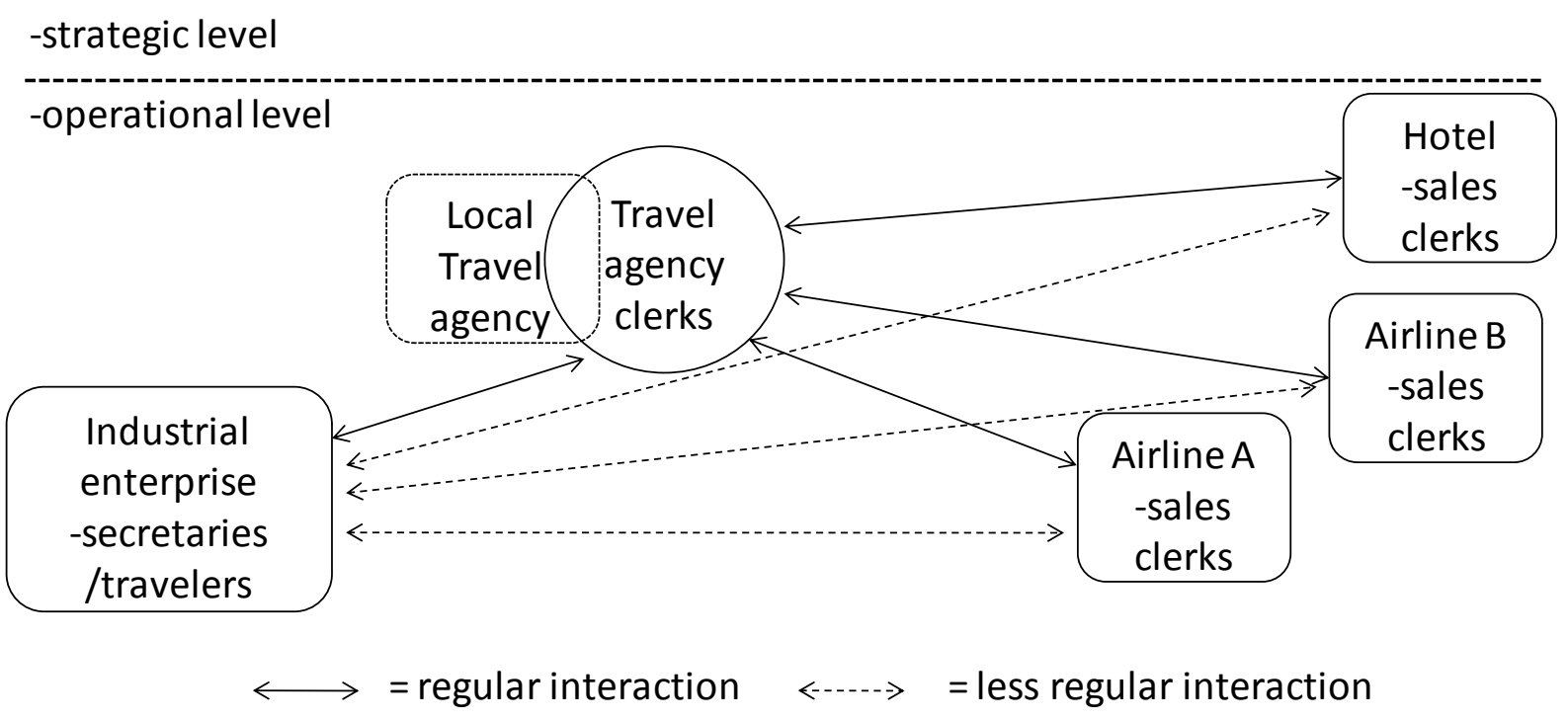

Fig. 6: Interpersonal interaction in industrial enterprise - local travel agency - supplier triads. 


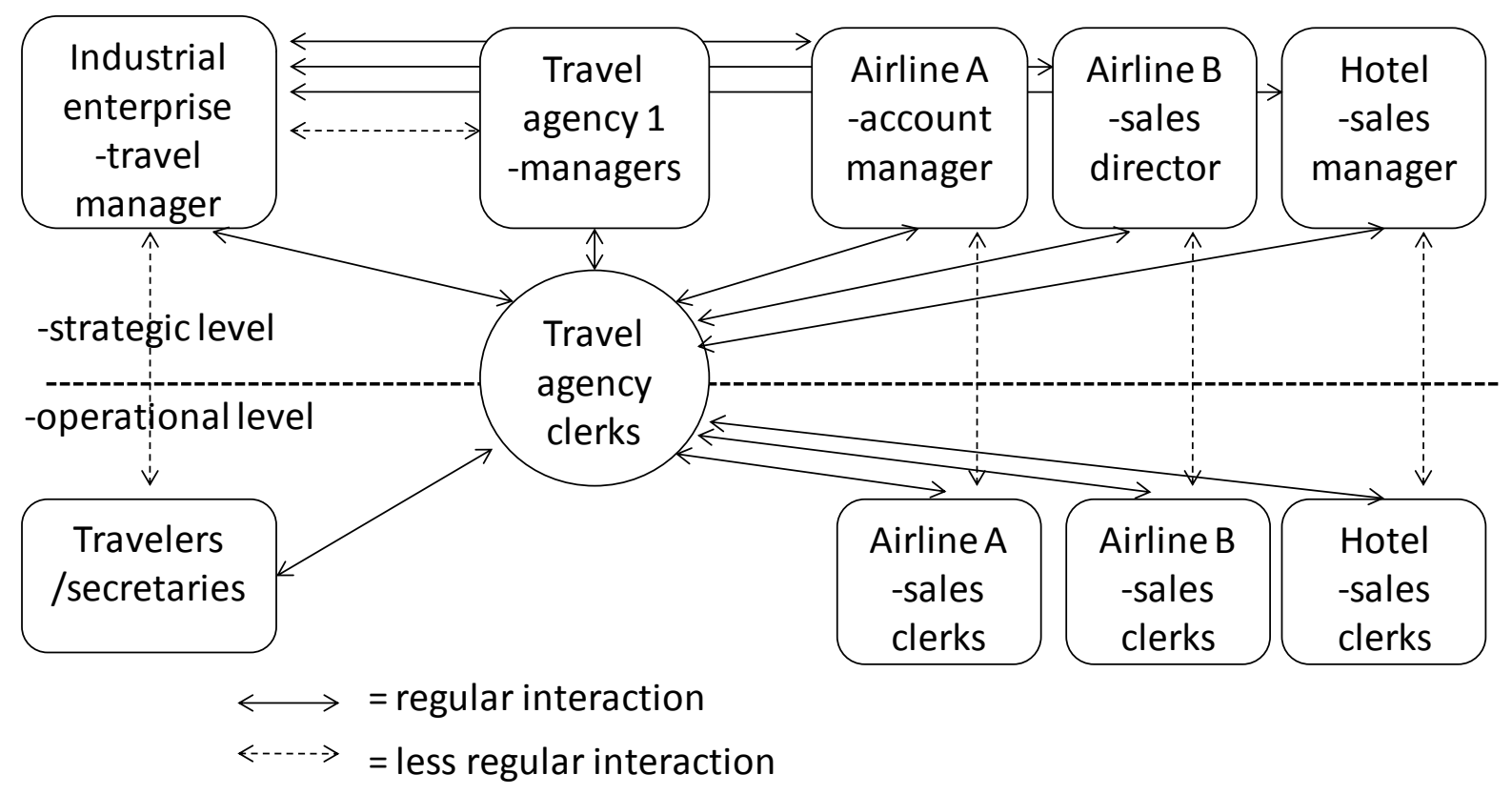

Fig. 7: Interpersonal interaction in industrial enterprise - travel agency 1 - supplier triads. 


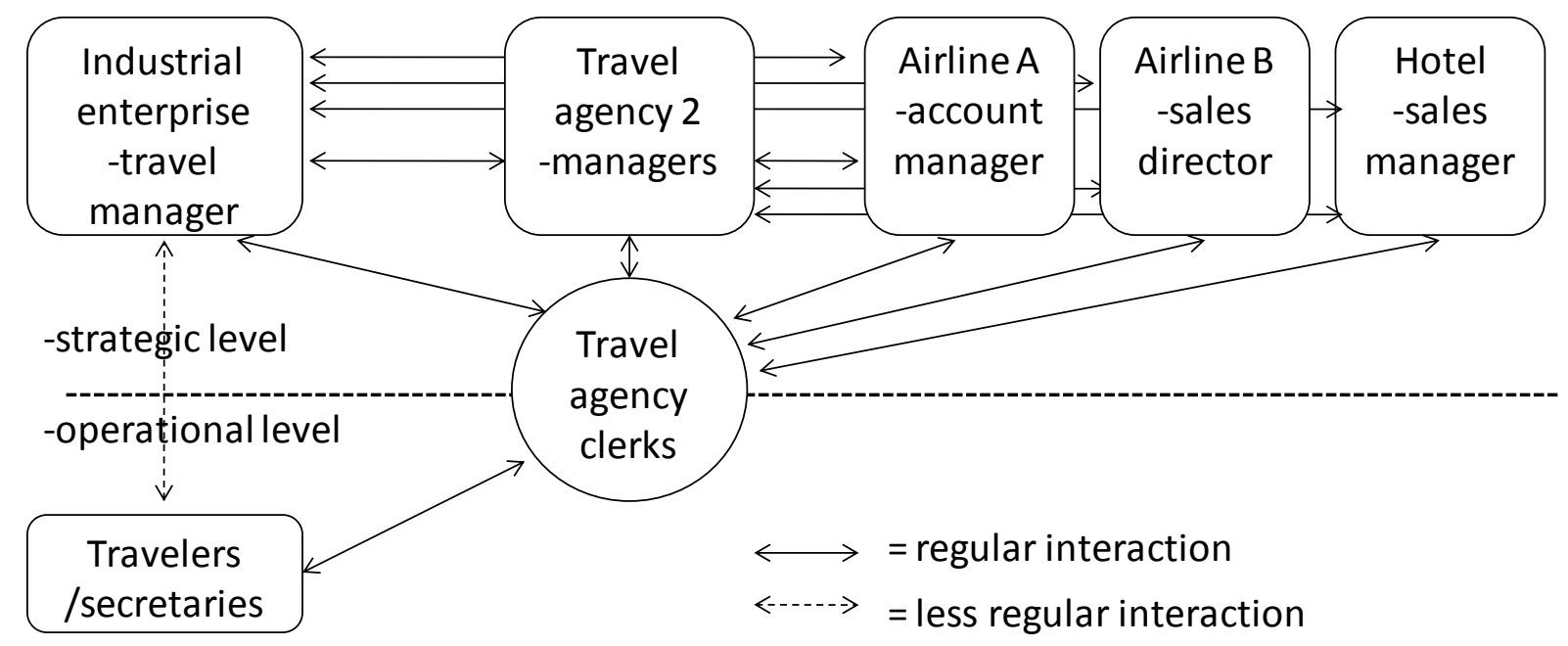

Fig. 8: Interpersonal interaction in industrial enterprise - travel agency 2 - supplier triads. 
Table 1: The informants and their connections to the corporate travel purchasing process.

\begin{tabular}{|c|c|c|c|}
\hline Informant & Present employer & Former employer & Functional level \\
\hline 1. Travel manager & Industrial enterprise & & $\begin{array}{l}\text { Strategic } \\
\text { End customer }\end{array}$ \\
\hline 2. Traveller & Industrial enterprise & & End customer \\
\hline \multirow[t]{3}{*}{ 3. Clerk } & Travel agency 1 & & Operational \\
\hline & & Travel agency 2 & Operational \\
\hline & & Travel agency 3 & Operational \\
\hline 4. General manager & Travel agency 2 & & Strategic \\
\hline \multirow[t]{2}{*}{ 5. District manager } & Travel agency 2 & & Strategic \\
\hline & & Travel agency 1 & Operational \\
\hline 6. Nordic manager & Travel agency 3 & & Strategic \\
\hline 7. Operations manager & Travel agency 3 & & Strategic \\
\hline \multirow[t]{2}{*}{ 8. Account manager } & \multirow[t]{2}{*}{ Airline A } & & Strategic \\
\hline & & Airline A & Operational \\
\hline 9. Sales director & Airline B & & Strategic \\
\hline \multirow[t]{2}{*}{ 10. Sales manager } & Hotel chain & & Strategic \\
\hline & & Hotel chain & Operational \\
\hline
\end{tabular}

